\title{
Application of Problem Based Learning (PBL) Model to Improve Higher Order Thinking Skills (HOTS)
}

\author{
Firda, Rizki Hadiwijaya, Fajar Nugraha \\ Universitas Perjuangan Tasikmalaya \\ firda1097@gmail.com
}

\section{Article History}

accepted 05/11/2020

approved 10/11/2020

published 01/02/2021

\begin{abstract}
This research was motivated by the low level of high-order thinking skills of students on the material of human respiratory organs at SDN Cibungbun, Tasikmalaya Regency, of 27 students only 9 students who completed getting high-order thinking skills scores, with very high criteria of 5 people, high criteria of 2 people. and the criteria are enough for 2 people. Based on this, the researcher applied the Problem Based Learning (PBL) learning model. This study used a Classroom Action Research (CAR) model. Data collection obtained through tests, observation, and documentation. The results obtained: 1) The application of the Problem Based Learning model increases Higher Order Thinking Skills. The results of the value of teacher activity in the first cycle increased from $78 \%$ in the good category, and in the second cycle to $93 \%$ in the very good category. 2) Increasing the results of students' higher order thinking skills. The results of students' high-order thinking skills in pre-cycle 63, then in cycle I with an average value of 72 , while in cycle II with an average value of 83. The results of research on teacher activity, student activity, and results of Higher Order Thinking Skills have changed towards a better direction, it can be concluded that the use of the PBL learning model can increase Higher Order Thinking Skills in class V SDN Cibungbun, Rajapolah District.
\end{abstract}

Keywords: problem based learning, HOTS

\begin{abstract}
Abstrak
Penelitian ini dilatarbelakangi oleh rendahnya keterampilan berpikir tingkat tinggi siswa pada materi organ pernapasan manusia di SDN Cibungbun Kabupaten Tasikmalaya, dari 27 orang siswa hanya 9 orang siswa yang tuntas mendapatkan nilai keterampilan berpikir tingkat tinggi, dengan kriteria sangat tinggi sebanyak 5 orang, kriteria tinggi 2 orang dan kriteria cukup sebanyak 2 orang. Berdasarkan hal tersebut peneliti menerapkan model pembelajaran Problem Based Learning (PBL). Penelitian ini menggunakan model Penelitian Tindakan Kelas (PTK). Pengumpulan data didapat melalui tes, observasi, dan dokumentasi. Hasil penelitian yang diperoleh: 1) Penerapan model Problem Based Learning meningkatkan Higher Order Thinking Skills. Hasil nilai aktivitas guru pada siklus I meningkat dari $78 \%$ dengan kategori baik, dan pada siklus II menjadi 93\% dengan kategori sangat baik. 2) Peningkatan hasil keterampilan berpikir tingkat tinggi siswa. Hasil keterampilan berpikir tingkat tinggi siswa pada pra siklus 63 , kemudian pada siklus I dengan nilai rata-rata 72 , sedangkan pada siklus II dengan nilai ratarata 83. Hasil penelitian aktivitas guru, aktivitas siswa, serta hasil keterampilan berpikir tingkat tinggi telah mengalami perubahan ke arah yang lebih baik, maka dapat disimpulkan bahwa penggunaan model pembelajaran PBL dapat meningkatkan Higher Order Thinking Skills di kelas V SDN Cibungbun Kecamatan Rajapolah.
\end{abstract}

Kata kunci: problem based learning, HOTS

Social, Humanities, and Education Studies (SHEs): Conference Series https://jurnal.uns.ac.id/shes

p-ISSN 2620-9284

e-ISSN 2620-9292 


\section{PENDAHULUAN}

Penyelenggaraan pendidikan sebagaimana yang diamanatkan dalam undangundang No. 20 Tahun 2003 "Tema pengembangan kurikulum 2013 adalah kurikulum yang dapat menghasilkan insan Indonesia yang produktif, kreatif, inovatif, afektif, melalui penguatan sikap, keterampilan dan pengetahuan dengan kompetensi inti meliputi sikap spiritual, sikap sosial, pengetahuan dan keterampilan" Permendikbud No 21 Tahun 2016. Untuk menyikapi tuntutan perubahan yang semakin kompetitif diperlukan perkembangan teknologi dan ilmu pengetahuan yang dapat mendorong perubahan proses kegiatan belajar mengajar kearah yang baik. Untuk itu, kurikulum 2013 yang diharapkan mampu memberi bekal kepada peserta didik memiliki kompetensi di masa depan. Salah satu muatan dalam kurikulum 2013 yaitu menuntut siswa untuk mampu berpikir tingkat tinggi/Higher Order Thinking Skills (HOTS) (Widowati, 2014).

Adapun hasil observasi di SDN Cibungbun bahwa keterampilan berpikir tingkat tinggi siswa pada pembelajaran IPA materi Organ Pernapasan Manusia masih rendah, sementara dalam kurikulum 2013 dituntut harus berpikir tingkat tinggi/Higher Order Thinking Skills. Proses belajar mengajar merupakan sarana untuk mentransformasikan nilai-nilai dan konsep-konsep pengetahuan dari pendidik ke siswa dengan memiliki tujuan yang telah di tetapkan. Seperti halnya beberapa kali pengamatan penulis dalam observasi di SDN Cibungbun Kecamatan Rajapolah pada siswa kelas $\mathrm{V}$ dengan muatan IPA menjadi salah satu muatan yang disajikan. Ditemukan fakta bahwa setiap proses belajar mengajar siswa cenderung pasif, siswa hanya mendengarkan materi kemudian mencatat hal-hal yang penting dari materi. Keadaan demikian memungkinkan interaksi belajar di kelas tidak berjalan dengan baik, bahkan untuk membangun kreatifitas dalam menemukan ide atau gagasan yang baru sangat minim. Berdasarkan hal tersebut perlu adanya suatu upaya guru, guna mengadakan perbaikan dalam pengelolaan proses pembelajaran sehingga dapat meminimalisir permasalahan tersebut, dengan memilih model, metode ataupun pendekatan pembelajaran yang kreatif dan inovatif. Maka penulis tertarik untuk menggunakan model pembelajaran yang dapat mengembangkan kemampuan berpikir siswa, model pembelajaran yang diterapkan tersebut adalah model Problem Based Learning (PBL). "Model ini menghadapkan siswa pada permasalahan sebagai dasar dalam pembelajaran yaitu dengan kata lain siswa belajar melalui permasalahan atau berdasarkan masalah" (Yamin 2013:68). Tujuan dari penelitian ini adalah untuk meningkatkan Higher Order Thinking Skills (HOTS) siswa kelas V di SDN Cibungbun dengan penerapan model Problem Based Learning (PBL).

Menurut Barrow (Huda, 2013:217) Problem Based Learning merupakan pembelajaran yang diperoleh melalui proses menuju pemahaman akan resolusi suatu masalah. Masalah tersebut dipertemukan dalam proses pembelajaran. Menurut Shoimin (2017:129) Model pembelajaran ini melatih dan mengembangkan kemampuan untuk menyelesaikan masalah yang berorientasi pada autentik dari kehidupan aktual siswa, untuk merangsang kemampuan berpikir tingkat tinggi. Tahapan-tahapan yang dilakukan guru dalam melaksanakan model Problem Based Learning (PBL) menurut Tan (Sani, 2018:215) adalah (1) Mengorientasikan peserta didik pada masalah, (2) Mengorganisasi peserta didik, (3) Membimbing penyelidikan individual maupun kelompok, (4) Menyajikan dan mengembangkan karya, (5) Menganalisis dan mengevaluasi proses penyelidikan.

Sebagai suatu model pembelajaran model Problem Based Learning (PBL) memiliki kelebihan dan kekurangan. Shoimin (2017:132) mengemukakan beberapa kelebihan dan kekurangan. Kelebihan dari model PBL yaitu (1) Siswa didorong untuk memiliki kemampuan memecahkan masalah dalam situasi nyata; (2) Siswa memiliki kemampuan untuk membangun pengetahuannya sendiri melalui aktivitas belajar; (3) Pembelajaran berfokus pada masalah sehingga materi yang tidak ada hubungannya 
tidak perlu dipelajari oleh siswa, hal itu mengurangi beban siswa dengan menghapal atau menyimak informasi; (4) Terjadi aktifitas ilmiah pada siswa melalui kerja kelompok; (5) Siswa terbiasa menggunakan sumber-sumber pengetahuan, baik dari perpustakaan, internet, wawancara dan observasi; (6) Siswa memiliki kemampuan menilai kemajuan belajarnya sendiri; (7) Siswa memiliki kemampuan untuk melakukan komunikasi ilmiah dalam kegiatan diskusi atau presentasi hasil pekerjaan mereka; dan (8) Kesulitan belajar siswa secara individual dapat diatasi melalui kerja kelompok dalam bentuk peer teaching. Sedangkan kekurangan model PBL adalah (1) Problem Based Learning tidak dapat diterapkan untuk setiap materi pelajaran, ada bagian guru berperan aktif dalam menyajikan materi; dan (2) Dalam suatu kelas yang memiliki tingkat keragaman siswa yang tinggi akan terjadi kesulitan dalam pembagian tugas.

Penerapan model Problem Based Learning (PBL) digunakan untuk meningkatkan Higher Order Thinking Skills (HOTS). Menurut Tomei (Sani, 2018:2) HOTS mencakup transformasi informasi dan ide-ide. Transformasi ini jika siswa menganalisa, mensintesa atau menggabungkan fakta dan ide, menggeneralisasi, menjelaskan atau sampai pada suatu kesimpulan. Manipulasi informasi dan ide-ide melalui proses tersebut akan memungkinkan siswa untuk menyelesaikan permasalahan, memperoleh pemahaman dan menemukan makna baru. Menurut Lewis dan Smith (Sani, 2018:2) berpikir tingkat tinggi akan terjadi jika seseorang memiliki informasi yang disimpan dalam ingatan dan memperoleh informasi baru, kemudian menghubungkan, atau menyusun dan mengembangkan informasi tersebut untuk mencapai suatu tujuan atau memperoleh jawaban yang mungkin untuk suatu situasi yang membingungkan.

\section{METODE}

Metode yang digunakan dalam penelitian ini adalah metode Penelitian Tindakan Kelas (PTK) atau Classroom Action Reseach (CAR) yang berfokus pada upaya mengubah kondisi nyata yang ada sekarang kearah yang digunakan. Penelitian ini bertujuan untuk perbaikan dan peningkatan layanan profesional pendidik dalam menangani proses pembelajaran (Arikunto, 20013:17). Jenis penelitian tindakan kelas yang digunakan merujuk pada model Kemmis dan McTaggart. Model Kemmis dan McTaggart pada hakikatnya berupa perangkat-perangkat dengan satu perangkat terdiri dari empat komponen yaitu perencanaan, pelaksanaan, pengamatan, dan refleksi merupakan satu siklus. Adapun model Kemmis dan McTaggart digambarkan sebagai berikut :

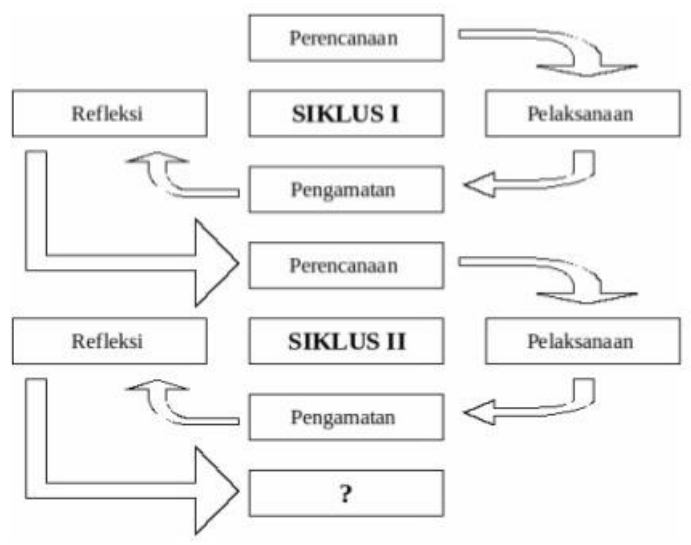

Gambar 1. Model PTK Kemmis dan McTaggart 
Penelitian ini dilaksanakan di SDN Cibungbun Kecamatan Rajapolah Kabupaten Tasikmalaya tahun ajaran 2019/2020. Subjek penelitian tindakan kelas adalah kelas $\mathrm{V}$ sebanyak 27 orang, yang terdiri dari 10 laki-laki dan 17 perempuan. Teknik pengumpulan data yang digunakan dalam penelitian ini untuk mencapai tujuan yaitu observasi, tes dan dokumentasi. 1) Teknik observasi yang digunakan untuk mengumpulkan data aktivitas siswa dan guru (peneliti) selama proses pembelajaran dengan menggunakan lembar aktivitas peneliti, lembar aktivitas siswa dengan memperhatikan sintaks model Problem Based Learning (PBL) pada setiap kegiatan pembelajaran berlangsung; 2) Tes yang digunakan dalam teknikpengumpulan data ini adalah tes tertulis untuk mengukur Higher Order Thinking Skills (HOTS) pada materi Organ Pernapasan Manusia, dengan memberikan soal evaluasi pada akhir pembelajaran setelah diterapkan model Problem Based Learning (PBL); 3) Dokumentasi bentuk dokumentasi pada penelitian ini antara lain RPP, silabus, daftar skor siswa, serta foto pada saat kegiatan pembelajaran dengan menggunakan model Problem Based Learning (PBL).

Teknik analisis data digunakan untuk menganalisis lembar observasi aktivitas guru dan siswa, serta peningkatan hasil tes Higher Order Thinking Skills (HOTS). Untuk menganalisis aktivitas guru dan siswa digunakan rumus :

$$
\text { Persentasi Skor Akhir }=\frac{\text { jumlah skor yang diperoleh }}{\text { jumlah skor maksimal }} \times 100 \%
$$

Sedangkan untuk menganalisis hasil tes digunakan rumus :

a. Penyekoran hasil tes sebagaimana dikemukakan Sudjana (2016:109) dengan rumus :

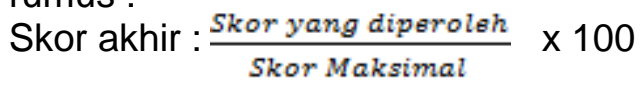

b. Mencari skor rata-rata siswa sebagaimana dikemukakan oleh Sudjana (2016:109) dengan rumus :

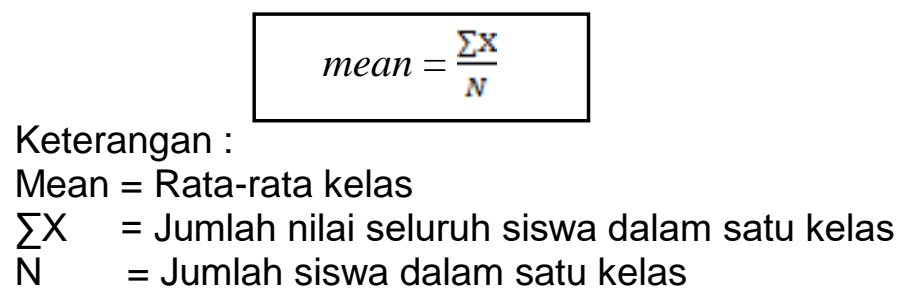
rumus :

Untuk menghitung persentase ketuntasan belajar siswa dapat dihitung dengan

$$
P=\frac{\text { jumlah siswa yang tuntas }}{\text { jumlah seluruh siswa }} \times 100 \%
$$

\section{HASIL DAN PEMBAHASAN}

Data yang diperoleh dari hasil penelitian berupa data hasil observasi terhadap aktivitas guru dan siswa selama proses pembelajaran dengan menggunakan model Problem Based Learning (PBL). Berikut ini disajikan tabel peningkatan aktivitas guru dan aktivitas siswa berdasarkan indikator yang terpenuhi dari hasil observasi aktivitas guru seperti pada tabel 1 sebagai berikut :

Tabel 1. Hasil Observasi Aktivitas Guru

\begin{tabular}{ccc}
\hline Siklus & Rata-rata & Persentase (\%) \\
\hline I & 3,10 & $78 \%$ \\
II & 3,73 & $93 \%$ \\
\hline
\end{tabular}


Berdasarkan tabel 1 hasil observasi aktivitas guru dalam proses pelaksanaan pembelajaran pada materi Organ Pernapasan Manusia menggunakan model Problem Based Learning (PBL) siklus I menunjukkan hasil yang "Baik". sedangkan pada siklus II terjadi peningkatan mendapatkan kategori "Sangat Baik". Adapun hasil observasi aktivitas siswa terperinci pada tabel 2 sebagai berikut :

\section{Tabel 2. Hasil Observasi Aktivitas Siswa}

\begin{tabular}{ccc}
\hline Siklus & Rata-rata & Persentase (\%) \\
\hline I & 2,75 & $69 \%$ \\
II & 3,5 & $87 \%$ \\
\hline
\end{tabular}

Berdasarkan tabel 2 hasil observasi aktivitas siswa dalam proses pelaksanaan pembelajaran pada materi Organ Pernapasan Manusia menggunakan model Problem Based Learning (PBL) siklus I menunjukkan hasil yang "Cukup". sedangkan pada siklus II terjadi peningkatan mendapatkan kategori "Baik"

Adapun persentase peningkatan Higher Order Thinking Skills (HOTS) dari siklus I dan siklus II dapat dilihat pada tabel 1 sebagai berikut :

Tabel 3. Rekapitulasi Antar Siklus

\begin{tabular}{ccc}
\hline Siklus & Siklus I & Siklus II \\
\hline Rata-rata & 72 & 82 \\
Persentase Ketuntasan & $52 \%$ & $81 \%$ \\
\hline
\end{tabular}

Terlihat bahwa dari siklus I ke siklus II terjadi peningkatan dengan rata-rata kelas dari 72 menjadi 82 dengan ketuntasan yang terjadi peningkatan $29 \%$ yaitu dari $52 \%$ menjadi $81 \%$. Persentase ketuntasan belajar yang ditentukan berdasarkan kriteria keberhasilan pada penelitian yaitu $80 \%$ siswa tuntas KKM yang telah ditentukan yaitu 75. Lebih jelasnya akan disajikan perbandingan jumlah siswa yang tuntas dan belum tuntas dalam grafik berikut ini :

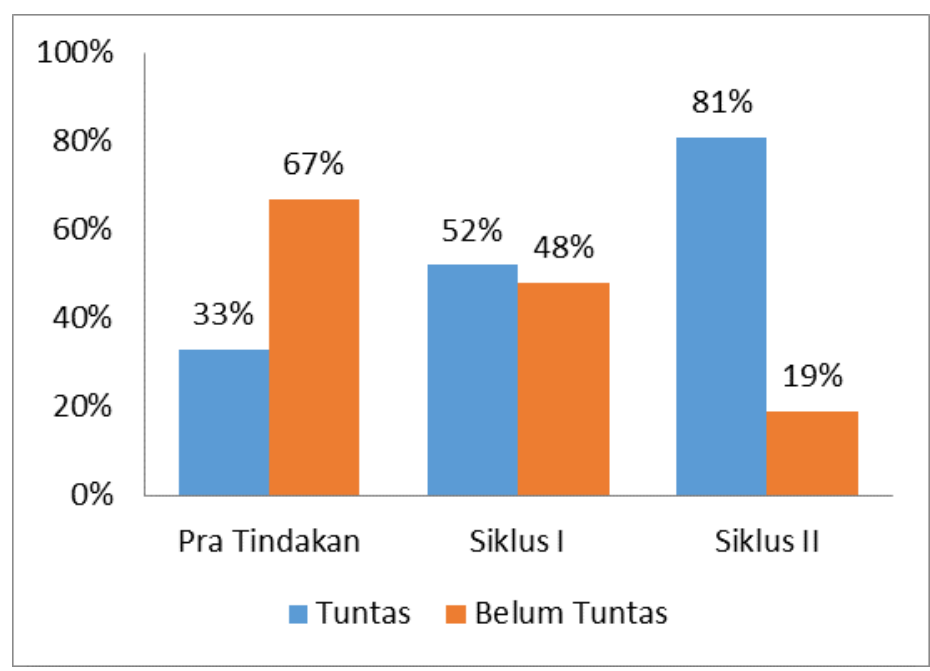

Gambar 2. Perbandingan Antar Siklus

Berdasarkan hasil penelitian maka terlihat perbaikan keterampilan berpikir tingkat tinggi siswa pada siklus pertama, pada latar belakang disampaikan beberapa permasalahan yang muncul di kelas V SDN Cibungbun pada mata pelajaran IPA yaitu rendahnya keterampilan berpikir tingkat tinggi, kurangnya keterlibatan siswa secara aktif dalam pembelajaran maka peneliti menguji soal tes skala terbatas, sehingga didapatkan $67 \%$ atau sekitar 18 siswa memiliki keterampilan berpikir tingkat tinggi masih rendah. Kondisi tersebut karena pembelajaran masih dilaksanakan dengan menggunakan metode ceramah, siswa hanya mendengarkan dan mencatat materi 
yang disampaikan oleh guru saja. Sehingga siswa tidak terlibat secara langsung dalam proses pembelajaran. Maka dari itu peneliti menerapkan model pembelajaran Problem Based Learning supaya siswa dapat memahami konsep IPA secara mendalam dan mampu menyelesaikan permasalahan berdasarkan kehidupan sehari-hari dengan keterampilan berpikir tingkat tinggi. Hal tersebut diperkuat oleh pendapat Menurut Shoimin (2017:129) Model pembelajaran ini melatih dan mengembangkan kemampuan untuk menyelesaikan masalah yang berorientasi pada autentik dari kehidupan aktual siswa, untuk merangsang kemampuan berpikir tingkat tinggi.

Persentase siswa yang memenuhi KKM pada pra tindakan sebanyak 9 orang siswa dengan persentase $33 \%$ sedangkan pada siklus I terjadi peningkatan siswa yang memenuhi KKM sebanyak 14 siswa dengan persentase $52 \%$ dan pada siklus II terjadi peningkatan siswa yang memenuhi KKM sebanyak 22 siswa dengan persentase $81 \%$, sedangkan terdapat siswa yang masih belum memenuhi KKM pada Pra tindakan sebanyak 18 orang dengan persentase $67 \%$, sedangkan pada siklus I terjadi penurunan sebanyak 13 orang dengan persentase $48 \%$ dan pada siklus II terjadi penurunan sebanyak 5 orang dengan persentase $19 \%$.

Berdasarkan hasil observasi dan data keterampilan berpikir tingkat tinggi siswa yang telah disajikan dalam hasil penelitian pada siklus I, aktivitas siswa $69 \%$ dengan kriteria cukup, hal tersebut mempengaruhi keterampilan berpikir tingkat tinggi siswa sehingga mengalami perbaikan yang dibuktikan dengan yang sudah memiliki keterampilan berpikir tingkat tinggi mendapat rata-rata nilai 72 dengan kriteria "Sedang", hal tersebut karena siswa melakukan proses pembelajaran dengan menggunakan model Problem Based Learning. Keterlaksanaan pembelajaran dengan model Problem Based Learning pada siklus I guru mendapatkan nilai dari observer sebesar 78\% mencapai kriteria "Baik". Selain dipengaruhi oleh keterlaksanaan pembelajaran oleh guru, meningkatkan keterampilan berpikir tingkat tinggi siswa juga dipengaruhi oleh aktivitas siswa dalam proses pembelajaran, seperti melakukan penyelidikan bersama kelompok dengan mencari informasi dan memecahkan permasalahan sendiri. Sehingga proses pembelajaran yang dilakukan tidak teacher center tetapi menjadi student center. Hal tersebut diperkuat oleh pendapat Menurut Lewis dan Smith (Sani, 2018:2) berpikir tingkat tinggi akan terjadi jika seseorang memiliki informasi yang disimpan dalam ingatan dan memperoleh informasi baru, kemudian menghubungkan, atau menyusun dan mengembangkan informasi tersebut untuk mencapai suatu tujuan atau memperoleh jawaban yang mungkin untuk suatu situasi yang membingungkan.

Selanjutnya pada siklus II, aktivitas siswa mengalami peningkatan menjadi $87 \%$ dengan kriteria baik, dengan demikian nilai keterampilan berpikir tingkat tinggi siswa mencapai rata-rata nilai 82 mencapai kriteria "Tinggi", dengan persentase siswa tuntas sebanyak 22 orang dengan persentase $81 \%$, sedangkan pada siklus II siswa yang tidak tuntas sebanyak 5 orang dengan persentase $19 \%$, hal tersebut terjadi karena siswa sulit dikondisikan saat proses kegiatan penyelidikan dalam kelompok. Namun dari kekurangan tersebut pembelajaran dengan menggunakan model Problem Based Learning dalam indikator HOTS siswa mengalami peningkatan, hal tersebut karena keterlaksanaan pembelajaran Problem Based Learning yang mencapai 93\% dalam kategori "Sangat Baik", artinya guru sudah mampu melaksanakan model Problem Based Learning dan aktivitas siswa dalam setiap kegiatan pada siklus II pun mengalami peningkatan, perolehan tersebut sudah memenuhi kriteria keberhasilan dari penelitian ini.

\section{SIMPULAN}

Berdasarkan hasil penelitian tindakan kelas yang telah dilaksanakan, maka dapat disimpulkan bahwa model pembelajaran Problem Based Learning dapat meningkatkan Higher Order Thinking Skills pada mata pelajaran IPA materi Organ 
Pernapasan Manusia. Adapun hasil yang di dapat dari setiap kegiatan pembelajaran yaitu pada aktivitas siswa terjadi peningkatan di siklus I 69\% dengan kriteria cukup dan pada siklus II $87 \%$ dengan kriteria baik, sedangkan pada aktivitas guru dalam siklus I $78 \%$ dengan kriteria baik dan pada siklus II 93\% dengan kriteria sangat baik. Dari data hasil aktivitas tersebut mempengaruhi nilai kemampuan ketermpilan berpikir tingkat tinggi pada siklus I skor rata-rata nilai keterampilan berpikir tingkat tinggi siswa yaitu 72 , dengan kategori sangat tinggi 4 orang (15\%), kategori tinggi 3 orang $(11 \%)$, kategori Sedang 18 orang (67\%) dan kategori rendah 2 orang (7\%). Sedangkan pada siklus II dengan nilai rata-rata keterampilan berpikir tingkat tinggi siswa 82, dengan kategori sangat tinggi 9 orang (33\%), kategori tinggi 12 orang (44\%), kategori sedang 6 orang (22), dan tidak ada yang mendapat nilai rendah. Dengan demikian secara keseluruhan keterampilan berpikir tingkat tinggi melalui model Problem Based Learning materi Organ pernapasan manusia telah terjadi peningkatan.

\section{DAFTAR PUSTAKA}

Arikunto, Suharsimi. 2013. Prosedur Penelitian Suatu Pendekatan Praktek. Jakarta: Rineka Cipta.

Huda Miftahul. 2013. Model-model Pengajaran dan Pembelajaran. Halm.217. Pustaka Pelajar:Yogyakarta.

Kemendikbud, 2016. Permendikbud 21 Tahun 2016 tentang Standar Isi Sekolah dasar dan Menengah. Jakarta Kementerian Pendidikan dan Kebudayaan.

Sani. Ra. 2018. Pembelajaran berbasis HOTS (Higher Order Thinking Skills). Halm.2 dan 215.Tsmart Printing: Medan

Shoimin Aris. 2017. Model Pembelajaran Inovatif Dalam Kurikulum 2013. Halm.129,130,132. Ar-RUZ Media:Yogyakarta.

Sudjana, Nana. 2016. Penilaian hasil proses belajar mengajar. Bandung : PT Remaja Rosdakarya

Widowati, A, 2014. Pembelajaran Sains HOT dengan Menerapkan Inquiry Laboratory, Jurnal Pendidikan, Pendidikan Biologi FMIPA UNY. http://staff.uny.ac.id/sites/default/files/13219972/Pembelajaran\%20Sains\%20HOT \%dengan\%20Menerapkan\%20Inquiry\%20Laboratory\%20Semnas\%20MIPA\%20 2010\%20UNY.pdf diakses 29 Januari 2020.

Yamin, Martinis, 2013. Strategi Dan Metode Dalam Inovasi Pembelajaran. Jakarta:Gaung Persada Press Group. 